Book Power in Communication, Sociology and Technology

Ed. Angela Repanovici, Manolis Koukourakis, Tereza Khecyoyan

Series: Philosophy, Communication, Media Sciences

Available online at http://trivent-publishing.eu/

\title{
Romanian Students' Perceptions of Bibliotherapy in the Educational Process
}

\author{
Daniela Popa, ${ }^{1}$ Ane Landoy, ${ }^{2}$ Angela Repanovici ${ }^{3}$ \\ ${ }^{1}$ The Faculty of Psychology and Education Sciences, \\ Transilvania University of Brasov, Romania, danapopa@unitbv.ro \\ ${ }^{2}$ Bergen University Library, Bergen University, Norway, ane.landoy@uib.no \\ ${ }^{3}$ Product Design and Environment Faculty, \\ Transilvania University of Brasov, Romania, arepanovici@unitbv.ro
}

\begin{abstract}
The use of bibliotherapy in the educational process leads to the improvement of students' skills to use the reading process in a more efficient way, to transfer knowledge while enjoying the process. This paper aims to identify the level of familiarity of first year university students with therapeutic techniques and also the benefit discovered in them by the new generations of students. We surveyed 111 students on their perception of bibliotherapy in the educational process. A social survey questionnaire was created and administered online. The findings provide useful information for librarians and top management in libraries in order to help bring potential bookmakers closer to the digital age.
\end{abstract}

Keywords: Student attitude; developmental bibliotherapy; digital age; reading therapy.

DOI: 10.22618/TP.PCMS.20181.156009

This is an Open Access article distributed in accordance with the Creative Commons Attribution Non Commercial (CC-BY-NC-ND 4.0) license, which permits others to copy or share the article, provided original work is properly cited and that this is not done for commercial purposes. Users may not remix, transform, or build upon the material and may not distribute the modified material (http:/ / creativecommons.org/ licenses/by-nc/4.0/) 


\title{
Romanian Students' Perceptions of Bibliotherapy in the Educational Process
}

\author{
Daniela Popa, ${ }^{1}$ Ane Landoy, ${ }^{2}$ Angela Repanovici ${ }^{3}$ \\ ${ }^{1}$ The Faculty of Psychology and Education Sciences, \\ Transilvania University of Brasov, Roman \\ ${ }^{2}$ Bergen University Library, Bergen University, Norway \\ ${ }^{3}$ Product Design and Environment Faculty, \\ Transilvania University of Brasov, Romania
}

\section{Introduction}

Bibliotherapy has a long history. Its first records were found in $300 \mathrm{BC}$ in the library of Alexandria, where the following description of reading was discovered: "the nourishment of the soul." 1 There are also reports on the use of reading for therapeutic purposes in Ancient Greece (Aristotle), in the Roman Empire, in the Middle Ages (religious texts), and up to the present.

Along with other environmental factors, such as family and community, school has an important role in the development of the individual, not only from a cognitive point of view, but especially from the psycho-moral and social perspective. Typical questions and age-specific dilemmas can find solutions and answers in carefully chosen readings. Likewise, strategies for coping with contemporary problems faced by today's students can be discovered through bibliotherapy, through a discreet pedagogy of the relevant facts.

Apart from the the well-known, general objective of bibliotherapy, some other objectives are the following: "1) guiding through reading; 2) using books to help solve personal problems; 3) developing life skills; 4) improving self-concept and personality, a dynamic interaction between readers' personality and literature." 2

In a broad sense, bibliotherapy is defined as "the guided reading of written materials in gaining understanding or solving problems relevant to a person's therapeutic needs" 3 Bibliotherapy is part of the activities related to wellness promotion, prevention and early intervention, as well as crisis intervention.

Bibliotherapy, as a practice has two directions of frequent use. One of them is the clinic approach, and the second is the educational one. Both types of therapy use different communication environments, from the direct one, in the form of individual and group

\footnotetext{
${ }^{1}$ Cardenas, M. E. "Bibliotherapy: Good book or media selection plus a definite goal." ERIC Document Reproduction Service ED, no. 191484 (April 1980): 193

2 Afolayan, J. A. "Documentary perspective of bibliotherapy in education." Reading Horizons 33, no. 2 (1992): 138

3 Riordan, R. J., and Wilson, L. S. "Bibliotherapy: Does it work?.” Journal of Counseling \& Development 67, no. 9 (1989): 506.
} 
counseling to online websites, included in the term e-health. ${ }^{4}$. In a narrow perspective, it delimitate "psycho-educational material, i.e., self-help manuals, which is a typical part of the adjunctive interventions" in clinical or educational treatment. ${ }^{5}$

Although there are opinions that consider that bibliotherapy should only be used by psychologists and counselors, a different perspective of developmental bibliotherapy "put forth the idea that bibliotherapy can be used in classrooms by teachers." 6 Teachers can use bibliotherapy in preventive counseling activities, for problem solving and developing socioemotional skills. ${ }^{7}$ The criteria for choosing the readings are closely related to students' needs.

The reading process facilitates the appearance of "opportunities for the imaginative projection of a subjective state into an object or person, a kind of self-identification and catharsis." 8 The next step allows the examination and generalization of new strategies for learning new behavior.9 The great advantage of bibliotherapy is the transfer of personal identities to the area of the characters discussed, namely outsourcing the problems, leading to conversations being less blocked and difficult. ${ }^{10} 11$

For the purpose of this research project, bibliotherapy is defined as: "the utilization of young-adult literature as an instructional strategy implemented by a classroom teacher to help adolescents better understand unknown concepts, cope with difficult situations, and address sensitive topics." 12

Current researches show that the use of bibliotherapy in the educational process improves students' skills using reading process in a very efficient way to transfer knowledge and enjoy the process. ${ }^{13} 14151617$

\footnotetext{
${ }^{4}$ Gunn, J., Cameron, J., Densley, K., Davidson, S., Fletcher, S., Palmer, V., Pirkis, J. et. All. "Uptake of mental health websites in primary care: Insights from an Australian longitudinal cohort study of depression." Patient Education and Counseling 101, no. 1. (2017): 105.

5 Rus-Makovec, M., Furlan, M., and Smolej, T. "Experts on comparative literature and addiction specialists in cooperation: A bibliotherapy session in aftercare group therapy for alcohol dependence." The Arts in Psychotherapy 44, (2015): 26.

${ }^{6}$ Leana-Taşcllar, M. Z. "The Use of Bibliotherapy in Classrooms for Gifted Students \& 58; A Bibliotherapy Model (Üstün Zekâlı ve Yetenekli Öğrencilerin de Bulunduğu Sınıflarda Bibliyoterapi Kullanımı\&58; Model Önerisi)." Turkish Journal of Giftedness and Education 2, no. 2 (2012): 118.

${ }^{7}$ Sullivan, Amie K., and Harold R. Strang. "Bibliotherapy in the classroom using literature to promote the development of emotional intelligence." Childhood Education 79, no.2 (2002): 74-80.

8 Leana-Tașcllar, M. Z. "The Use of Bibliotherapy in Classrooms for Gifted Students \& 58; A Bibliotherapy Model (Üstün Zekâlı ve Yetenekli Öğrencilerin de Bulunduğu Sınıflarda Bibliyoterapi Kullanımı\&58; Model Önerisi)." Turkish Journal of Giftedness and Education 2, no. 2 (2012): 119.

9 Marchant, M., \& Womack, S. "Book in a bag: Blending social skills and academics." Teacbing Exceptional Children 42, no.4 (2010): 6-12.

${ }^{10}$ Heath, M.A., Sheen, D., Leavy, D., Young, E. \& Money, K. "Biliotherapy: A resource to facilitate emotional healing and growth." School Psychology 26 (2005): 563-580.

${ }^{11}$ Zambo, D. "What can you learn from Bombaloo? Using picture books to help young students with special needs regulate their emotions." Teaching Exceptional Children 39, (2007): 32-39.

12 Camp, R. D., "Perceptions of bibliotherapy: a survey of undergraduate students." (Graduate Theses and Dissertations, Iowa State University 14645, 2015).

${ }^{13}$ Russell, D. H., and Shrodes, C. "Contributions of Research in Bibliotherapy to the Language-Arts Program. I." The School Review 58, no.6 (1950): 335-342.

${ }_{14}$ Haeseler, L. A. "Biblio-therapeutic book creations by pre-service student teachers: Helping elementary school children cope." Journal of Instructional Psychology 36, no. 2 (2009): 113-119.

15 McCulliss, D., \& Chamberlain, D. "Bibliotherapy for youth and adolescents-School-based application and research." Journal of Poetry Therapy 26, no.1 (2013): 13-40.
} 


\section{Methods}

\section{Aims and review questions}

This paper's aim is to identify the level of familiarity of first year students with bibliotherapy as well as the benefits discovered by digital born generation of students.

\section{Design}

A survey research design was employed to assess the perceptions of bibliotherapy quantitatively. This research design was selected to describe the perceived attitudes and behaviors of the undergraduate students in the Transilvania University. We adopted the Camp R. D. questionnaire (2015) to the Romanian language and population.

The survey consist of demographics information section and three other sections, with predominately closed response questions that asked participants to rate items using a predetermined summative scale. The questionnaire has 29 items, of which 5 are sociodemographic, 5 are open questions, and 19 items are quoted on a psychometric rating scale from 1 to 4 (1=Very uncomfortable, 2=Uncomfortable, 3=Comfortable, 4=Very comfortable).

We were interested in:

- Student's experiences and current understandings of bibliotherapy;

- How acceptable the participants perceived bibliotherapy;

Participants' perceived comfort using bibliotherapy in a classroom setting.

\section{Procedure}

The survey was administered online using social media networks such as Facebook, Google and Yahoo. Students were asked to answer as honestly as possible Informed consent was done before completing the survey. The rights and potential risks to which they were exposed through participation in this research has been explained. As well, subjects have been assured of the privacy of their personal data.

\section{Population}

We surveyed 111 students from Transilvania University of Braşov. The data collection period was from the 1st to the 12th of October, 2017. The group of participants consist of 99 female $89,2 \%$ and 12 male 10,8\%. The participants were first year students in the following faculties: Medicine 66,7\%, Psychology and Sciences of Education 4,5\%, Economical Sciences 14,4\%, Law 1,2\%, Sociology 6,3\%, Product Design and Environment $6,3 \%$.

The participants age ranged from 18 and 41 years old, with the following percentages: $57,6 \%$ between $18-20$ years old, $33,3 \%$ between $21-23$ years old, $2,7 \%$ between $24-26$ years old, and 6,3\% between $28-41$ years old.

\footnotetext{
${ }^{16}$ Gerlach, H., and Subramanian, A. "Qualitative analysis of bibliotherapy as a tool for adults who stutter and graduate students." Journal of fluency disorders 47, (2016): 1-12.

17 Papi, A., Mosharraf, Z., Farashbandi, F. Z., Samouei, R., \& Hassanzadeh, A. "The effect of bibliotherapy on the psychological capital of the staff of the School of Management and Medical Informatics of Isfahan University of Medical Science." Journal of Education and Health Promotion (2017): 6:31.
} 


\section{Results}

\section{The level of familiarity of first year students with bibliotherapy}

The statistical analysis shows that $25,2 \%$ of students received information about bibliotherapy before completing the survey. A large sub-group $(74,8 \%)$ had no contact with any form of bibliotherapy.

Due to the questionnaire being administered online, immediately upon receiving access to the subjects were given the following definition: "Bibliography is not an specialization of psychology, it is a set of techniques that involve the recommendation of certain reading (fiction, non-fiction, comics, articles, poetry, etc.) and the viewing of audiovisual materials, writing texts, performing artistic activities, to treat certain life problems and / or to help deal with certain disorders". This was done with regard to familiarity with specific techniques. After reading this explanation, the subjects were able to further complete the questionnaire.

The following question, "What is bibliotherapy for you?" implied free answers. These were the subject of a qualitative analysis. Synthesizing their answers, most student representations of bibliotherapy were described as: "A way to relax, to get out of the daily routine, to disconnect me from everything that is routine"; "Opening new horizons, another point of view"; "At first glance, bibliotherapy seems to be a method that can be used to deal with some of the inner issues of the being. By being into contact with certain situations, or certain experiences, through books, film, or any other form of art, individuals can internalize those experiences and especially can empathize with them, reaching a deeper understanding of one's own being."; "Bibliotherapy is a creative way to help treat an emotional state of an individual and also an opportunity for these people to interact with specialists to improve them".

The next item, "How would you define bibliotherapy according to your knowledge, your experience?", also requested open answers. Students define bibliotherapy as: "For me, this is a way to develop, both intellectually and emotionally"; "In my opinion, bibliotherapy helps us be more optimistic and have the courage to dare to do things we fear"; "I would define bibliotherapy as a way to understand the world as well as the inner world through other people. You can understand the world through the eyes of others, without living yourself through flesh and bones that experience."; "Bibliotherapy is a noninvasive, beautiful and relaxing method for treating the soul, mind and body."

\section{Perception of the acceptability level in approaching educational goals through bibliotherapy}

After knowing the meaning given to the term "bibliotherapy," students were asked to project in the pedagogical situation where the teacher would use the specific literature for children and young people in the course. They were asked to establish the level of acceptability/ comfort in addressing certain themes.

Thus, the researchers selected goals and received the scores highlighted in Table 1. Students' perception of the goals. As we can see, the main educational goals with a very strong impact on students are: to develop the vocabulary, to give students hope and inspiration, to develop fluency in reading and to promote healthy self-esteem. 
Table 1. Students' perception of the goals

\begin{tabular}{|c|l|c|c|c|}
\hline No & \multicolumn{1}{|c|}{ Items } & Average & SD & CI \\
\hline $\mathbf{1 .}$ & To discuss the phenomenon of harassment & 3,09 & 0,848 & $2,94-3,25$ \\
\hline $\mathbf{2 .}$ & $\begin{array}{l}\text { To help the class of students understand a } \\
\text { colleague with dyslexia }\end{array}$ & 3,47 & 0,724 & $3,34-3,59$ \\
\hline $\mathbf{3 .}$ & To develop the vocabulary & 3,71 & 0,529 & $3,61-3,81$ \\
\hline $\mathbf{4 .}$ & $\begin{array}{l}\text { To connect a student with a character } \\
\text { experiencing a similar situation or feelings }\end{array}$ & 3,39 & 0,822 & $3,23-3,54$ \\
\hline $\mathbf{5 .}$ & To develop empathy & 3,38 & 0,832 & $3,21-3,53$ \\
\hline $\mathbf{6 .}$ & To discuss a student's illness & 2,84 & 0,977 & $2,66-3,03$ \\
\hline $\mathbf{7 .}$ & To entertain students & 3,02 & 0,981 & $2,82-3,20$ \\
\hline $\mathbf{8 .}$ & $\begin{array}{l}\text { To help a student overcome the death of } \\
\text { someone dear }\end{array}$ & 3,02 & 0,914 & $2,85-3,19$ \\
\hline $\mathbf{9 .}$ & To overcome the death of an animal & 2,86 & 0,962 & $2,68-3,05$ \\
\hline $\mathbf{1 0 .}$ & To introduce a scientific concept & 3,32 & 0,811 & $3,17-3,49$ \\
\hline $\mathbf{1 1 .}$ & To give students hope and inspiration & 3,68 & 0,556 & $3,58-3,78$ \\
\hline $\mathbf{1 2 .}$ & To practice problem solving skills & 0,819 & $3,32-3,63$ \\
\hline $\mathbf{1 3 .}$ & To promote healthy self-esteem & 3,57 & 0,696 & $3,43-3,70$ \\
\hline $\mathbf{1 4 .}$ & $\begin{array}{l}\text { To provide students with information on a new } \\
\text { / unknown subject }\end{array}$ & 3,50 & 0,712 & $3,36-3,63$ \\
\hline $\mathbf{1 5 .}$ & To show students quality illustrations & 3,23 & 0,904 & $3,05-3,41$ \\
\hline $\mathbf{1 6 .}$ & To promote the development of social skills & 3,43 & 0,746 & $3,30-3,58$ \\
\hline $\mathbf{1 7 .}$ & For a student with behavioral disorders & 3,11 & 0,898 & $2,94-3,28$ \\
\hline $\mathbf{1 8 .}$ & To develop fluency in reading & 3,62 & 0,661 & $3,49-3,73$ \\
\hline
\end{tabular}

$\mathrm{SD}=$ standard deviation $\mathrm{CI}=$ confidence interval

\section{The benefits discovered by digital born generation of students}

The participants in this study discover the following advantages in using bibliotherapy in educational settings: enriching the vocabulary, enthusiasm to read, student integration in society, information and training in various cases, "drawing students' attention to feelings and how important it is to treat painful situations, because they influence their behavior and attitude in adolescence," relaxation, tranquility, development of social skills, communication, development of imagination, development of self-confidence, positive thinking, emotional development, cognitive development, promoting values and qualities (e.g., gentleness, honesty, empathy), self-esteem, respect for oneself and others, self-knowledge.

\section{Factors that influence the implementation in educational settings}

The purpose of Part Three of the survey was to address the following research questions: What factors influence the level of comfort in implementing bibliotherapy as an instructional tool in the classroom?; and, What concerns do student's hold in regards to bibliotherapy implementation? The answers received to the first question refer to the teachers' competences to introduce bibliotherapy in educational context, the timeliness and adequacy of the reading and the facility of introducing it into the school curriculum. There are very few concerns student's hold in regards to bibliotherapy implementation. The main concerns are: "some materials could not solve pupils'/teen's disturbances and they could still be disappointed"; "Sometimes you need to understand the figurative meanings in the book (at least in the case of science fiction books, because we do not have supernatural 
powers), but most readers do not try to understand the mystery of the story, so they cannot be found in characters"; "The only thing that can be unclear is the students' openness to reading the books. Sometimes people do not want to be helped."

\section{Discussion. Conclusions}

This paper highlights that bibliotherapy is still in its nascent period in Romania. The study shows that students are enthusiastic about receiving such an initiative in an educational context. The differences between the two main directions are: clinical and developmental bibliotherapy are not very clear to students. One reason can be the fact that they did not experience the developmental bibliotherapy, another can be the teachers' needs to solve difficult situations and behavior problems in classroom settings. But it is necessary to understand that "developmental bibliotherapy seeks to guide individuals in coping with life's challenges in a manner that aids personal development" (Camp, 2015, p. 92).

In line with the literature, these conclusions support the importance for teachers to communicate with all involved parts about their teaching, about including developmental bibliotherapy in the educational process and to increase awareness about the advantages it has.

One of the weaknesses of this study is the limited number of male students. Because of this, we couldn't make comparisons between genders. The research tool is self-responding, and therefore may be biased by social desirability.

These findings provide useful information for the librarians and top management in libraries to help bring potential readers closer to this institution. Future studies will include comparing the perceptions of those who did not have the chance to explore bibliotherapy with those who did. Future research should focus on the efficacy of developmental bibliotherapy in educational context, teacher action research in this area and follow-up studies.

\section{References}

Afolayan, Johnson. A. "Documentary perspective of bibliotherapy in education." Reading Horizons 33, no. 2 (1992): 137-148.

Camp, R. D., "Perceptions of bibliotherapy: a survey of undergraduate students." (Graduate Theses and Dissertations, Iowa State University 14645, 2015). http://lib.dr.iastate.edu/etd/14645

Cardenas, M. E.. "Bibliotherapy: Good book or media selection plus a definite goal." ERIC Document Reproduction Service ED, no. 191484 (April 1980): 191-484.

Gerlach, H., and Subramanian, A. "Qualitative analysis of bibliotherapy as a tool for adults who stutter and graduate students." Journal of fluency disorders 47, (2016): 1-12.

Gunn, J., Cameron, J., Densley, K., Davidson, S., Fletcher, S., Palmer, V., Pirkis, J. et. all. "Uptake of mental health websites in primary care: Insights from an Australian longitudinal cohort study of depression." Patient Education and Counseling 101, no. 1 (2017): 105-112.

Haeseler, L. A. "Biblio-therapeutic book creations by pre-service student teachers: Helping elementary school children cope.” Journal of Instructional Psychology 36, no. 2 (2009): 113119.

Heath, M.A., Sheen, D., Leavy, D., Young, E. \& Money, K. "Biliotherapy: A resource to facilitate emotional healing and growth." School Psychology 26 (2005): 563-580.

Leana-Taşc1lar, M. Z. "The Use of Bibliotherapy in Classrooms for Gifted Students \& 58; A Bibliotherapy Model (Üstün Zekâlı ve Yetenekli Öğrencilerin de Bulunduğu Sınıflarda 
Bibliyoterapi Kullanımı\&58; Model Önerisi)." Turkish Journal of Giftedness and Education 2 no. 2 (2012): 118-136.

Marchant, M., \& Womack, S. "Book in a bag: Blending social skills and academics." Teaching Exceptional Children 42, no.4 (2010): 6-12.

McCulliss, D., \& Chamberlain, D. "Bibliotherapy for youth and adolescents-School-based application and research.” Journal of Poetry Therapy 26, no.1 (2013): 13-40.

Papi, A., Mosharraf, Z., Farashbandi, F. Z., Samouei, R., \& Hassanzadeh, A. "The effect of bibliotherapy on the psychological capital of the staff of the School of Management and Medical Informatics of Isfahan University of Medical Science." Journal of Education and Health Promotion (2017): 6:31.

Riordan, R. J., \& Wilson, L. S. “Bibliotherapy: Does it work?” Journal of Counseling \& Development 67, no. 9 (1989): 506-508.

Rus-Makovec, M., Furlan, M., \& Smolej, T. "Experts on comparative literature and addiction specialists in cooperation: A bibliotherapy session in aftercare group therapy for alcohol dependence." The Arts in Psychotherapy 44, (2015): 25-34.

Russell, D. H., \& Shrodes, C. "Contributions of Research in Bibliotherapy to the LanguageArts Program. I." The School Review 58, no.6 (1950): 335-342.

Sullivan, Amie K., and Harold R. Strang. "Bibliotherapy in the classroom using literature to promote the development of emotional intelligence." Childhood Education 79 no.2 (2002): 74-80.

Zambo, D. "What can you learn from Bombaloo? Using picture books to help young students with special needs regulate their emotions." Teaching Exceptional Children 39, (2007): 32-39. 